\section{Endelig en bok om palliasjon ved luftveissykdommer}

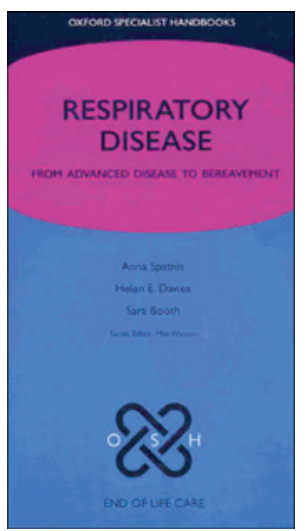

Anna Spathis, Helen E. Davies, Sara Booth Respiratory disease

From advanced disease to bereavement. 297 s, tab, ill. Oxford: Oxford University Press, 2011. Pris GBP 38

ISBN 978-0-19-956403-3

Luftveissykdommer er en stadig hyppigere dødsårsak. Det er derfor påfallende hvor lite det er skrevet om palliativ omsorg for denne pasientgruppen. Desto mer gledelig er det å lese denne boken i Oxford Specialist Handbook-serien. Den primære målgruppen er leger under spesialistutdanning i lungemedisin og palliativ medisin, samt leger, sykepleiere og annet helsepersonell som arbeider med palliativ omsorg for pasienter med luftveissykdommer.

Forfatterne er en lungespesialist og to spesialister i palliativ medisin, og de har som ett av sine utgangspunkt at utøvere av ett av de to fagene vil ha behov for en oppdatering i det andre. Derfor begynner de med en gjennomgang av luftveissykdommer som for en lungespesialist fortoner seg som nokså basal, men som sikkert kan være til nytte for en som ikke primært arbeider med dette feltet. Spesielt setter jeg stor pris på den edruelige omtalen av oksygenbehandling. Deretter følger en systematisk gjennomgang av palliative problemstillinger. I tillegg til de spesifikke luftveisrelaterte symptomene tar de for seg temaer som smerte, utmattelse (fatigue), angst, depresjon, søvnproblemer, vekttap, kvalme og obstipasjon.

Akuttsituasjoner er viet god plass, med temaer som lungeembolisme, vena cava superior-syndrom, pleuraeffusjon, luftveisobstruksjon og hemoptyse. Gitt at rammen for boken er omsorg i sluttfasen, kan man nok undres over et høyt ambisjonsnivå, f.eks. når forfatterne anbefaler kirurgisk behandling ved massiv hemoptyse, og man knapt diskuterer akutt terminal sedering som et alternativ ved den sjeldne dramatiske hemoptysen i terminalfasen. Problemstillingene omkring palliativ sedering ved terminal omsorg er i det hele tatt ikke omtalt.

Kapitlet om kommunikasjon med pasient og pårørende er velskrevet. Likeledes er det prisverdig at bidragsyterne tar for seg tverrfaglig (multidisciplinary) samarbeid og retter oppmerksomheten mot etiske overveielser og hvordan man kan imøtekomme pasientens åndelige og eksistensielle behov.

Boken er liten og tynn, med et «billig» utseende og lite holdbar paperbackinnbinding. Det er lett å overse den i bokhandlerens hyller. Når den da til alt overmål er gitt den lite presise tittelen Respiratory disease, er det ikke lett å få tak i hva den egentlig dreier seg om. Den er dyr, med en pris som ligger $30 \%$ over bøkene i forlagets innholdsrike og solid innbundne serie i samme format.

Men om man overvinner disse hindringene, finner man en innholdsrik, konsis og anvendelig bok med nyttig informasjon så vel for leger og sykepleiere som for andre som arbeider med denne pasientgruppen. Boken kan med fordel være tilgjengelig for alle grupper av helsepersonell ved lungeavdelinger og ved enheter for lindrende behandling.

\section{Livet på sykehjemmet}

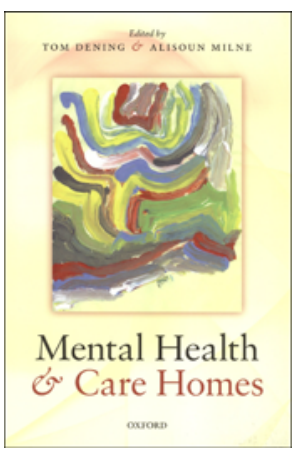

Tom Dening, Alisoun Milne, red Mental health and care homes

386 s, tab, ill. Oxford: Oxford University Press, 2011. Pris GBP 35

ISBN 978-0-19-959363-7

Dette er en sammenhengende og kunnskapsbasert oversikt over emner om mental helse i ulike institusjoner for eldre. Forekomsten av mentale helseproblemer er høy og relativt lite undersøkt. Målgruppen er personer som er engasjert i temaet, studenter, profesjonelle yrkesgrupper og forskere. Boken er hendig og lettlest og vil også ha interesse for eldre selv og pårørende.

Forfatterne ønsker å skape diskusjon og få til en bedre praksis slik at omsorgs- og livskvaliteten bedres for institusjonsbeboerne. Om ikke vi alle kommer på sykehjem eller i en eldrebolig, vil livskvalitet i eldre år angå de fleste av oss på en eller annen måte.

De fire delene med til sammen 26 kapitler er skrevet av 38 bidragsytere. Den første delen handler om livet på sykehjemmet sett innenfra med en beboers, en pårørendes og en bestyrers øyne. Det handler også om det kreative arbeidet som foregår der. Andre del omhandler sykehjemmet sett utenfra, lovregulerte krav til kvalitet og kvalitetskontroll, betalingsordninger, forebygging av misbruk og langtidsomsorg $\mathrm{i}$ et internasjonalt perspektiv. I den tredje delen beskriver forfatterne ulike modeller for hvordan allmenn- og sykehjemsleger og spesialister på best mulig måte kan knyttes til omsorgen. Her handler det om spesielle behov hos personer med demens og depresjon og hos minoriteter som fargede, lesbiske og homofile. Forfatterne gir mange eksempler på psykososial intervensjon, støtte og palliativ omsorg i siste del av livet. Siste del handler om hvordan man i fremtiden kan fremme helse og velbefinnende, og forfatterne gir mange eksempler på god praksis. Selv om noe av stoffet handler om situasjonen i Storbritannia, er det meste overførbart til vår virkelighet. Tabellene er mange og interessante.

Det er oppmuntrende at temaet om mental helse hos eldre beboere begynner å få mer oppmerksomhet, både hos politikere og fagfolk. Bidragsyterne kommer med mange viktige innspill for å høyne standarden på omsorgen. De gir en god beskrivelse av hvordan man fremmer personsentrert og relasjonssentrert omsorg, og hvordan personalet kan trenes opp til å gi optimal hjelp til personer med demens i ulike faser.

I dag blir beboerne lett marginalisert, og de er ofte usynlige i debatten om god livskvalitet. Forventningene til omsorgen blir stadig større. Man ønsker å legge mer vekt på autonomi, valg og gode tjenester, slik at flere velger sykehjemmet som eget hjem når man trenger mer støtte, $i$ stedet for at oppholdet ses på som et uunngåelig siste oppholdssted før døden.

Styrken er at boken er fremtidsrettet og at forfatterne lykkes med å beskrive både den helsemessige og sosiale delen av omsorgen. Søkelyset på forskning og økt livskvalitet, med synspunkter både innenfra og utenfra, gjør boken aktuell for leger og andre interesserte.

Kjell Martin Moksnes

Alderspsykiatrisk avdeling

Klinikk psykisk helse og avhengighet

Oslo universitetssykehus 